Faculty of Agriculture, Omudrman Islamic University, P.O. Box 382 Sudan

\title{
EFFECT OF FEEDING DIFFERENT LEVELS OF MAIZE OIL ON PERFORMANCE OF BROILER CHICKS
}

(With 7 Tables)

By

SAFA M.A. EL TAZI

(Received at 2/5/2010)

\section{SUMMARY}

The effect of feeding different levels of maize oil on performance of broiler chicks was studied. One-hundred and twenty one day-old, unsexed (Lohmann) broiler chicks were randomly divided into four experimental groups. Each group was further subdivided into five replicates at the rate of six chicks per pen in complete randomized design. The birds were fed on four levels of maize oil $(0,2,4$ and $6 \%)$ with constant level of dietary protein $(22 \%)$ for 7 -weeks duration. Health of the stock and performance parameters were recorded. At the end of the experiment, energy balance parameters and chemical composition data were measured and recorded. The results indicated that, weight gain, feed intake, feed efficiency, energy utilization percentage and carcass fat content of broiler chicks were significantly $(\mathrm{P}<0.01)$ affected by different levels of maize oil. Birds fed the high oil level $6 \%$ showed better results in body weight gain, feed efficiency, energy utilization percentage and higher carcass fat content with the lowest feed intake as compared to other experimental groups. The broiler chicks can utilize maize oil till $6 \%$ in their diet more efficiency as compared to other levels.

Key words: Broiler chicks, high energy diets, maize oil.

\section{INTRODUCTION}

Recently the demand for poultry production has increased due to the increase in population. In order to achieve optimum broiler production, high energy diets have been recommended for rapid broiler growth and efficient feed utilization. In this respect, fats and vegetable oil has been extensively utilized in broiler diets to raise the energy density, in addition to benefit from their high efficient utilization for 
tissue synthesis and lipogensis. The energy from the dietary oil and fat sources is known to be more efficiently utilized for body fat synthesis than dietary carbohydrates or protein (De-Groote et al., 1971). However, limited local research has been conducted to determine the adequate level of vegetable oil for feeding broiler chicks under open-housing system in Sudan.

This study was intended to gain more information about the effect of feeding different levels of maize oil on performance of broiler chicks.

\section{MATERIALS and METHODS}

A number of 130 chicks were used in this experiment, 10 chicks were selected randomly and sacrificed by the dislocation of the neck, without loss of blood, and prepared for determination of the initial carcass composition. The remaining 120 chicks were randomly distributed into 4 groups of 30 chicks. Each group was further subdivided into 5 replicates with 6 chicks per each. The chicks of each replicate were housed in a pen (1 square meter) in an open-sided deep litter house. Four levels of maize oil $(0,2,4$ and 6\%) with constant dietary protein level $22 \%$ were fed during the experimental period for 7 weeks duration. All the experimental diets were formulated to meet the nutrient requirements of broiler chicks according to NRC (1994) which were formulated from the local feed ingredients commonly used for poultry feeding in the Sudan. Calculated analysis of the experimental diets was done according to feedstuff analysis outlined by Ellis (1981), while determined chemical analysis was conducted by the method of AOAC (1988). Formulation and proximate analysis and calculated analysis for the experimental diets are shown in Tables (1 and 2) respectively, while chemical composition of the super concentrate used in the diets is shown in Table (3). Feed and water were offered adlibitum. The light was continuous throughout of the experimental period. The performance of the experimental birds in term of feed intake, live weight gain and feed efficiency were recorded weekly. Health of the experimental stock and mortality rate were closely observed and recorded daily.

At the end of $7^{\text {th }}$ week six birds were selected at random from each treatment, leg branded and kept overnight without feed. They were then reweighed individually and three birds from the selected six birds of each group were scarified and used for carcass analysis. The ten 
chicks selected at the start of the experiment for initial carcass analysis, and the three birds selected from each treatment at the end of the experimental period were prepared for carcass analysis.

Table 1: Formulation and proximate analysis of the experimental diets (percent as fed)

\begin{tabular}{|l|c|c|c|c|}
\hline Ingredients & $0 \%$ & $2 \%$ & $4 \%$ & $6 \%$ \\
\hline A: Formulation levels & $0 \%$ & & & \\
\hline Grain sorghum & & 63 & 61 & 59 \\
\hline Groundnut meal & 65 & 13 & 15 & 17 \\
\hline Sesame meal & 16 & 14 & 12 & 10 \\
\hline Super concentrate & 5 & 5 & 5 & 5 \\
\hline Oyster shell & 2.75 & 2.75 & 2.75 & 2.75 \\
\hline Common salt & 0.25 & 0.25 & 0.25 & 0.25 \\
\hline Vegetable oil & 0 & 2 & 4 & 6 \\
\hline Total & 100 & 100 & 100 & 100 \\
\hline B: Determined analyies & & & & \\
\hline Dry matter & 95.90 & 96.30 & 97.90 & 98.40 \\
\hline Crude protein (N\% x 6.25) & 22.21 & 22.60 & 22.21 & 22.78 \\
\hline Ether extract & 4.59 & 6.86 & 8.37 & 8.66 \\
\hline Crude fibre & 4.80 & 4.90 & 4.70 & 4.60 \\
\hline Ash & 9.38 & 9.28 & 8.58 & 9.56 \\
\hline Nitrogen free extract & 54.92 & 52.66 & 54.04 & 52.80 \\
\hline
\end{tabular}

Table 2: Calculated analyses of the experimental diets - dry matter basis (DM)

\begin{tabular}{|l|c|c|c|c|}
\hline \multicolumn{1}{|c|}{ Oil levels } & $0 \%$ & $2 \%$ & $4 \%$ & $6 \%$ \\
\hline $\begin{array}{l}\text { Items } \\
\text { (Kcabolikg) }\end{array}$ & 2974 & 3085 & 3197 & 3308 \\
\hline Crude fat & 5.59 & 7.33 & 9.10 & 10.86 \\
\hline Crude protein & 22.12 & 22.12 & 22.12 & 22.12 \\
\hline Lysine & 1.07 & 1.08 & 1.09 & 1.10 \\
\hline Methionine & 0.52 & 0.49 & 0.47 & 0.47 \\
\hline Cystine & 0.32 & 0.32 & 0.32 & 0.30 \\
\hline Methionine + cystine & 0.84 & 0.81 & 0.79 & 0.77 \\
\hline Calcium & 1.10 & 1.07 & 1.03 & 1.00 \\
\hline Available phosphorous & 0.70 & 0.68 & 0.68 & 0.67 \\
\hline $\begin{array}{l}\text { Calroie-protein ratio } \\
\text { (ME Kcal/kg: protein \%) }\end{array}$ & 134 & 139 & 145 & 150 \\
\hline
\end{tabular}

*Metabolizable energy: calculated according to [6] 
Table 3: Chemical composition of the super concentrate used in the diet formulation (Hendrix broiler concentrate)

\begin{tabular}{|l|c|}
\hline Metabolizable energy & $1900(\mathrm{Kcal} / \mathrm{kg})$ \\
\hline Crude protein & $32.00 \%$ \\
\hline Lysine & $11.00 \%$ \\
\hline Methionine & $2.80 \%$ \\
\hline Methionine + cystine & $2.25 \%$ \\
\hline Calcium & $8.00 \%$ \\
\hline Available phosphorus & $5.00 \%$ \\
\hline
\end{tabular}

They were weighed individually and then killed by cervical dislocation without loss of blood. Each group of birds from each experimental treatment were weighed separately and prepared to form one total homogeneous mass, from which a representative sample was taken for drying. Each whole carcass was cut into small pieces with along knife and was passed through Alexanderwerk vertical cutter. The feathers were cut into short lengths to facilitate easy and better mincing without causing frequent blockage in the mincer outlet or overheating of the electric motor. The product was then transferred to Stephen Universal Machine Mincer and was reduced to a fine paste. It was passed through this machine twice for ten minutes continuous mincing each time in order to obtain a finely divided and homogenous mass. About 50 grams of this mass was sampled and dried to a constant weight. The dried product was then ground to fine homogenous powder, and sampled for carcass analyses. The determination of gross energy for these samples was done by using Gallenkamp Autobomb Calorimeter. The initial and the final energy content of the experimental birds, on each of the experimental diets, was calculated and the energy retention was measured by a comparative slaughter technique. The metabolizable energy content of the experimental diets were determined in separate trail using the total collection method. The remaining three birds selected from each treatment were used for determination of chemical composition. They were slaughtered and dissected. The breast and thigh of each carcass were deboned and minced twice and then kept frozen for determination of their chemical composition. Statistical analysis were made by analysis of variance for a completely randomized design, according to Steel and Torrie (1986). 


\section{RESULTS}

The effect of feeding different levels of maize oil on broiler's performance is shown in Table (4). The body weight gain and feed conversion ratio were improved significantly $(\mathrm{P}<0.01)$ as the level of oil was increased, while the total feed intake tended to decreased significantly $(\mathrm{P}<0.01)$ with the increasing level of oil. The diet with the highest level of oil $(6 \%$ added oil) showed significantly $(\mathrm{P}<0.01)$ the highest body weight gain and the best feed conversion ratio with the lowest feed intake as compared to the other experimental groups.

As shown in Table (5), all the experimental diets stimulated adequate nutrient intake at all levels of oil (NRC, 1994).

Table 4: Effect of feeding different maize oil levels on the performance of broiler chicks (0-7 weeks)

\begin{tabular}{|l|c|c|c|c|c|}
\hline \multicolumn{1}{|c|}{ Oil levels } & $0 \%$ & $2 \%$ & $4 \%$ & $6 \%$ & SEM \\
\hline Parameter & & & & & \\
\hline Initial live weight (g/chick) & 45.31 & 45.13 & 45.50 & 45.09 & - \\
\hline Final live weight (g/chick) & $1727.5^{\mathrm{d}}$ & $1847.5^{\mathrm{c}}$ & $1940.5^{\mathrm{b}}$ & $2030.0^{\mathrm{a}}$ & $6.32^{* *}$ \\
\hline Body weight gain (g/chick) & $1682.2^{\mathrm{d}}$ & $1802.4^{\mathrm{c}}$ & $1894.5^{\mathrm{b}}$ & $1984.9^{\mathrm{a}}$ & $6.32^{* *}$ \\
\hline Total feed intake (g/chick) & $3989.8^{\mathrm{a}}$ & $3906.6^{\mathrm{b}}$ & $3865.8^{\mathrm{c}}$ & $3840.0^{\mathrm{d}}$ & $11.8^{* *}$ \\
\hline Feed conversion ratio & $2.37^{\mathrm{a}}$ & $2.16^{\mathrm{b}}$ & $2.04^{\mathrm{c}}$ & $1.93^{\mathrm{d}}$ & $0.007^{* *}$ \\
\hline
\end{tabular}

SEM: Standard error of the means

**: Highly significant $(\mathrm{P}<0.01)$.

Table 5: Feed and nutrients intake during the experimental period (0-7 weeks) (g/chick)

\begin{tabular}{|l|c|c|c|c|c|}
\hline \multicolumn{1}{|c|}{ Oil levels } & $\begin{array}{c}\text { NRC } \\
\text { Parameter }\end{array}$ & $0 \%$ & $2 \%$ & $4 \%$ & $6 \%$ \\
\hline Feed intake & - & 3989.8 & 3906.6 & 3865.8 & 3840.0 \\
\hline $\begin{array}{l}\text { Metablizable energy } \\
\text { intake (Kcal/chick) }\end{array}$ & 8750 & 10788 & 11195 & 11520 & 11985 \\
\hline Protein intake & 693 & 845 & 828 & 819 & 814 \\
\hline Lysine & 34.4 & 41.8 & 41.8 & 41.7 & 41.7 \\
\hline Methionine + cystine & 23.9 & 32.4 & 31.0 & 30.0 & 28.5 \\
\hline
\end{tabular}


Table (6) shows the effect of feeding different oil levels on the metabolizable energy utilization by the experimental birds during the whole experimental period. The data show the partitioning of the total metabolizable energy consumed (Kcal/chick), over the whole experimental period, into its components of energy retention and total heat production. The energetic efficiency for the conversion of the metabolizable energy consumed to body tissue energy is also shown in the same table. The data indicated that the metabolizale energy consumption, energy retention, total heat production and efficiency of the energy utilization were significantly $(\mathrm{P}<0.01)$ affected by the dietary treatments. The metabolizable energy intake (Kcal/chick), the energy retention (Kcal/chick) and the efficiency of metabolizable energy utilization were improved significantly $(\mathrm{P}<0.01)$ as the level of oil was increased, while the total heat production (Kcal/chick) was decreased as the level of oil was increased in the diets.

As shown in Table (7), the effect of feeding different oil levels on chemical composition of breast and thigh muscles of broiler. There was no significant difference $(\mathrm{P}>0.05)$ in the percentage of protein, ash and moisture for both breast and thigh muscles of broiler among the experimental treatments except the fat percentage. Birds fed the diet with high oil level $6 \%$ produced significantly $(\mathrm{P}<0.01)$ the highest carcass fat percentage while those fed the diet with the lowest oil level $0 \%$ produced the lowest fat percentage for both breast and thigh muscles of broiler.

On the other hand, the experimental treatments had no significant $(\mathrm{P}>0.05)$ effect on the mortality rate. Only one bird from each treatment died, which cannot be related in any way to the experimental treatments.

Table 6: Energy balance data for chicks fed the experimental diets.

\begin{tabular}{|l|c|c|c|c|c|}
\hline \multicolumn{1}{|c|}{ Oil levels } & $0 \%$ & $2 \%$ & $4 \%$ & $6 \%$ & SEM \\
\hline $\begin{array}{l}\text { Metabolizable energy intake } \\
\text { (Kcal/chick) }\end{array}$ & $10787.8^{\mathrm{d}}$ & $11195.4^{\mathrm{c}}$ & $11519.9^{\mathrm{b}}$ & $11985.2^{\mathrm{a}}$ & $30.60^{* *}$ \\
\hline Energy retention (Kcal/chick) & $5215.6^{\mathrm{d}}$ & $6026.1^{\mathrm{c}}$ & $6753.2^{\mathrm{b}}$ & $8715.2^{\mathrm{a}}$ & $24.70^{* *}$ \\
\hline Total heat production (Kcal/chick) & $5572.2^{\mathrm{a}}$ & $5169.2^{\mathrm{b}}$ & $4766.6^{\mathrm{c}}$ & $3270.0^{\mathrm{d}}$ & $33.00^{* *}$ \\
\hline Energy utilization (\%) & $48.3^{\mathrm{d}}$ & $53.9^{\mathrm{c}}$ & $58.6^{\mathrm{b}}$ & $72.6^{\mathrm{a}}$ & $0.22^{* *}$ \\
\hline
\end{tabular}

SEM: Standard error of the means

:** Highly significant $(\mathrm{P}<0.01)$. 
Table 7: Chemical composition of breast and thigh muscles of broiler chicks

\begin{tabular}{|c|c|c|c|c|c|}
\hline $\begin{array}{c}\text { Oil levels } \\
\text { Parameter }\end{array}$ & $0 \%$ & $2 \%$ & $4 \%$ & $6 \%$ & SEM \\
\hline Breast: & & & & & \\
\hline Fat \% & $10.87^{\mathrm{d}}$ & $12.55^{\mathrm{c}}$ & $13.23^{\mathrm{b}}$ & $15.83^{\mathrm{a}}$ & $0.33^{* *}$ \\
\hline Protein \% & 22.50 & 22.47 & 22.34 & 22.21 & $0.31^{\mathrm{NS}}$ \\
\hline Moisture & 62.27 & 62.39 & 62.52 & 62.73 & $0.15^{\mathrm{NS}}$ \\
\hline Ash & 2.06 & 2.03 & 2.02 & 2.06 & $0.15^{\mathrm{NS}}$ \\
\hline Thigh: & & & & & \\
\hline Fat \% & $11.90^{\mathrm{d}}$ & $13.72^{\mathrm{c}}$ & $14.51^{\mathrm{b}}$ & $16.42^{\mathrm{a}}$ & $0.34^{* *}$ \\
\hline Protein \% & 22.39 & 22.31 & 22.19 & 22.05 & $0.32^{\mathrm{NS}}$ \\
\hline Moisture & 63.72 & 63.81 & 63.75 & 63.90 & $0.14^{\mathrm{NS}}$ \\
\hline Ash & 1.69 & 1.62 & 1.65 & 1.72 & $0.17^{\mathrm{NS}}$ \\
\hline
\end{tabular}

SEM: Standard error of the means

**: Highly significant $(\mathrm{P}<0.01)$.

NS: Not statistically significant $(\mathrm{P}>0.05)$

\section{DISCUSSION}

The effect of feeding different levels of maize oil on the productive performance of broiler is shown in Table (4). Treatment effect on body weight gain, feed intake and feed efficiency was highly significant $(\mathrm{P}<0.01)$. Birds fed the diet that contained $6 \%$ maize oil level produced significantly $(\mathrm{P}<0.01)$ the highest body weight gain and the lowest feed consumption with the best feed utilization efficiency as compared to other experimental groups. The experimental birds tended to adjust their feed intake according to the oil level by eating less from the high oil level diets. The highest body weight gain and the best feed utilization efficiency were attained by the birds fed the highest level of oil diet. These effects were consistent with the increased nutrients intake from the different experimental diet (Table 5).

The response to the increased oil level can be attributed to the increased metabolizable energy intake. These results coincided with the finding of Waldroup (1996) who reported that, incorporation of high-oil maize up to $6 \%$ of broiler diet, during the starter and grower periods (till 42 days of age) produced significantly heavier birds and improved feed conversion efficiency. These results were in line with the finding of Benitez et al. (1999) who mentioned that significantly higher body weight gain $(\mathrm{P}<0.05)$ was obtained by the birds fed the high-oil maize during the first 42 days of age. 
Similar results were obtained by Rutkowski et al. (1998) who recorded that feed intake was decreased and live weight gain was increased with fat supplementation. The improvement in the performance parameters has been explained by the increased metabolziable energy intake from the diet with higher maize oil level which would consequently promote the metabolic processes of growth in form of synthesis of flesh and body fat.

The incorporation of maize oil resulted in improved efficiency of energy utilization (Table 6). Energy retention (Kcal/chick) was significantly $(\mathrm{P}<0.01)$ increased with increasing the maize oil level. This was accompanied by a progressive reduction in total heat production and consequent improvement in the efficiency of energy utilization. The metabolizable energy intake was progressively increased with increasing maize oil level. The total heat production, on the other hand, was reduced with the higher maize oil level. This pattern of reduction in heat production indicates a better efficiency of energy utilization for body tissue synthesis with increasing the level of maize oil. As the result of this, the birds fed the diet with the highest incorporation level of maize oil had significantly $(\mathrm{P}<0.01)$ the lowest total heat production (Kcal/chick), together with the highest level of energy retention and the highest percentage of energy utilization. These results were in line with other finding (Carew and Hill, 1964; Fuller and Rendon, 1979; Grimbergen et al., 1982; El-Tazi, 2001) who indicated that, energy from dietary fat sources would improved energy retention and increased the efficiency of energy utilization by broiler chickens. This effect is attributed to the comparatively low heat increment with the diets containing fat, as a result of the efficient utilization of fatty acids for lipogenesis (Blaxter, 1989).

The chemical composition of the breast and thigh muscles confirms the effect of increasing the maize oil level which increased the fat content of the carcasses. Birds fed the diet that contained $6 \%$ maize oil produced the highest carcass fat content, while those fed the diet that contained $0 \%$ maize oil produced the lowest of these values. This effect can be attributed to the addition of maize oil in the diets which would have improved lipogensis and intramuscular fat deposition (El-Tazi, 2001).

It could be concluded that the broiler chicks could be utilize maize oil till $6 \%$ in their diet with more efficient. 


\section{REFERENCES}

AOAC (1988): Official Methods of Analytical (12 $2^{\text {th }}$ ed) Association of Official Analytical Chemists, Washington, D.C., USA.

Benitez, J.A.; Gernat, A.G.; Murillo, J.G. and Araba, M. (1999): The use of high oil corn in broiler diets. Poult. Sci., 78 (6): 861-865.

Blaxter, K.L. (1989): Energy metabolism in animals and man, pp. 255289. Cambridge University Press, Cambridge, Great Britain.

Carew, L.B. JR and Hill, F.W. (1964): Effect of corn oil on metabolic efficiency of energy utilization by chicks. J. Nutrition, 283-293.

De-Groote, G.; Reyntens, N. and Amich Gali (1971): Fat Studies. 2. The metabolic efficiency of energy utilization of glucose, soyabean oil and different animal fats by growing chicks. Poult. Sci., 50: 808-819.

Ellis, N. (1981): The nutrient composition of Sudanese animal feeds. Bull. 1. Central animal nutrition research laboratory, Kuku, Khartoum North.

El-Tazi, S.M.A. (2001): The effect of dietary energy and protein utilization on performance and carcass quality of broiler chicken under Sudan condition. Ph.D. Thesis, University of Khartoum, Sudan.

Fuller, H.L. and Rendon, M. (1979): Energetic efficiency of corn oil and poultry fat at different levels in broiler diets. Poult. Sci., 58 (5): 1234-1238.

Grimbergen, A.H.M.; Stappers, H.P. and Cornelissen, J.P. (1982): The influence of an isocaloric substitution of soyabean oil for carbohydrates and of the nutrient density of the feed on growth and efficiency of energy utilization in broiler chickens. Netherlands-Journal-of-Agriculture- Science, 30 (2): 115-125.

NRC (National Research Council) (1994): Nutrient requirements of poultry. $9^{\text {th }}$ Rev. ed National Academy Press, Washington, DC.

Rutkowski, A.; Sliwinski, B. and Wiaz, M. (1998): Efficiency of vegetable or animal fat in mixtures for broiler chickens. Roczniki-Naukowe-Zootechniki, 25 (1): 67-74.

Steel, R.G.D. and Torrie, J.H. (1986): Principles and Procedures of Statistics: A Biometrical Approach (2 ${ }^{\text {nd }}$ ed.) McGraw Hill Book Company, Inc. NY, USA.

Waldroup, P.W. (1996): Considering high-oil corn in broiler diets should include potential enhancements. Feedstuffs. 68 (27): 12-14. 